\title{
Phaon Crescent, Mat Plant Crescent, Physiodes phaon (Edwards) (Insecta: Lepidoptera: Nymphalidae) ${ }^{1}$
}

\author{
Donald W. Hall and Jerry F. Butler ${ }^{2}$
}

\section{Introduction}

The phaon crescent is a common southern crescent that frequents moist open areas. It resembles the pearl crescent that is found in the same areas, but differs by the more checkered fringe on the wings.

\section{Distribution}

The phaon crescent is found from coastal North Carolina throughout the southern parts of the Gulf states to southern Texas and westward to Southern California. It strays north to Iowa and Nebraska.

\section{Description}

The wingspread is 14 to $16 \mathrm{~mm}$. The upper surface of the wings is brown with orange checker spots (Figure 1) and the front wings have a median white to yellowish band (also visible on the undersides). The undersides of the wings are orange and light tan with blackish brown markings.

Larvae (Figure 2) are variable in color from olive to brown with dark subdorsal bands and white lateral bands. Both thoracic and abdominal segments

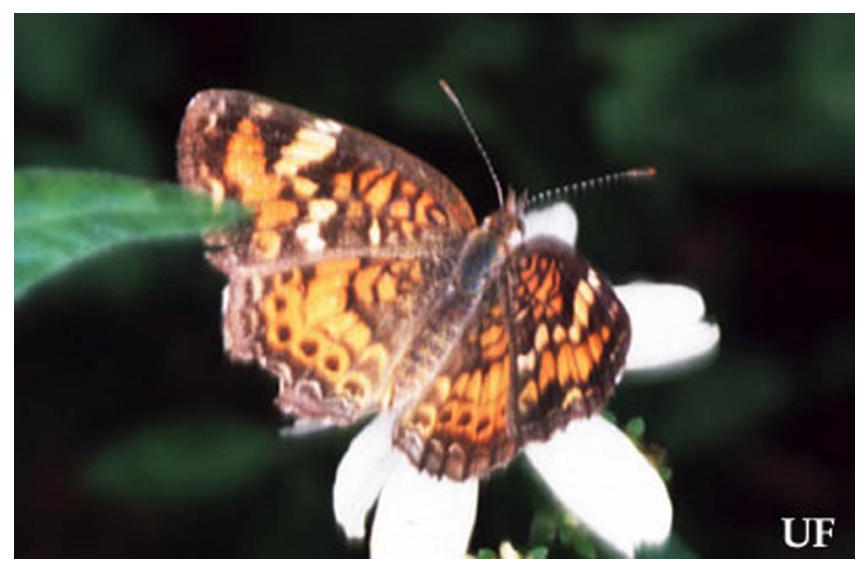

Figure 1. Adult phaon crescent, Phyciodes phaon (Edwards). Credits: Jerry F. Butler, University of Florida

have transverse bands of scoli each of which bears brown setae.

\section{Life Cycle}

There are several flights (early spring to late fall) in the northern part of the range and nearly year round in peninsular Florida. Males patrol open areas near host plants for females. Mating occurs primarily during mid day. Eggs are laid in clusters on the undersides of leaves of the fogfruit host plants, Phyla (=Lippia) spp. (Verbenaceae). The common host

1. This document is EENY-109, one of a series of the Entomology and Nematology Department, Florida Cooperative Extension Service, Institute of Food and Agricultural Sciences, University of Florida. Original publication date August 1999. Reviewed May 2003. Visit the EDIS Web Site at http://edis.ifas.ufl.edu.

2. Donald W. Hall, professor and Jerry F. Butler, professor, Entomology and Nematology Department, Institute of Food and Agricultural Sciences, University of Florida, Gainesville, FL.

The Institute of Food and Agricultural Sciences (IFAS) is an Equal Opportunity Institution authorized to provide research, educational information and other services only to individuals and institutions that function with non-discrimination with respect to race, creed, color, religion, age, disability, sex, sexual orientation, marital status, national origin, political opinions or affiliations. U.S. Department of Agriculture, Cooperative Extension Service, University of Florida, IFAS, Florida A. \& M. University Cooperative Extension Program, and Boards of County Commissioners Cooperating. Larry Arrington, Dean 


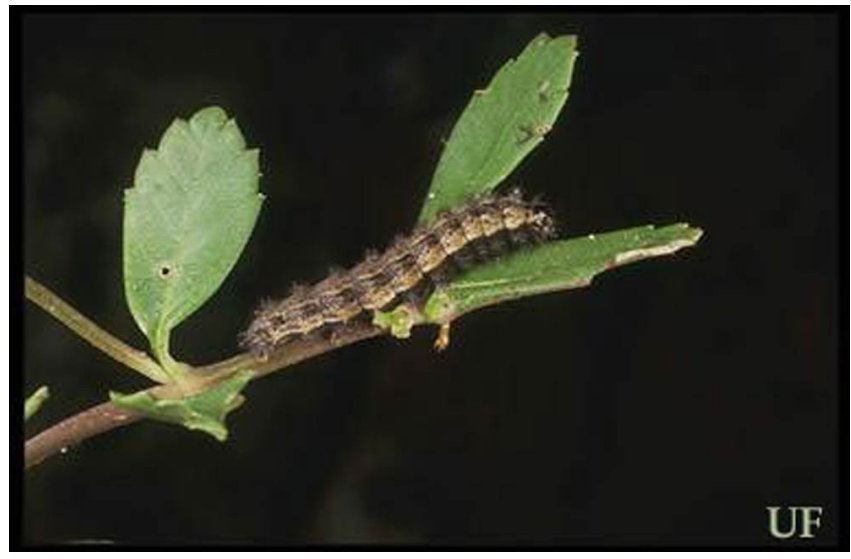

Figure 2. Larva of phaon crescent, Phyciodes phaon (Edwards). Credits: Jerry F. Butler, University of Florida

throughout much of Florida is turkey tangle fogfruit, Phyla nodiflora (L.) Green also known as capeweed, mat plant, creeping charlie, and match heads (Figure $3)$.

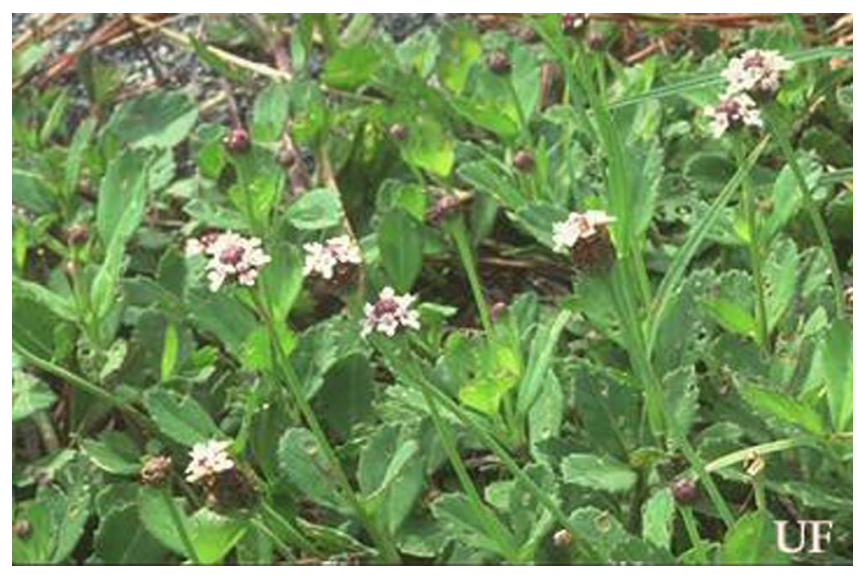

Figure 3. Turkey tangle fogfruit, Phyla nodiflora (L.) Green (Verbenaceae). Credits: Donald W. Hall, University of Florida

\section{Selected References}

Gerberg, E.J. and R.H. Arnett. 1989. Florida Butterflies. National Science Publications, Inc. Baltimore, MD.

Minno, M.C. and T.C. Emmel. 1993. Butterflies of the Florida Keys. Scientific Publishers.

Gainesville, Florida.

Opler, P.A. and G.O. Krizek. 1984. Butterflies East of the Great Plains. The Johns Hopkins University Press. Baltimore, MD.
Opler, P.A. and V. Malikul. 1998. Eastern Butterflies. Peterson Field Guide Series. Houghton Mifflin Company. New York.

Scott, J.A. 1986. The Butterflies of North America. Stanford University Press. Stanford, CA. 